\title{
A new record of Tillandsia candida Leme (Bromeliaceae, Tillandsioideae) and notes on its taxonomy
}

\author{
Rayssa Valentim ${ }^{1,2}$ and (D) Rafael Louzada ${ }^{1}$
}

Received 14.02.2019; accepted 18.12.2019

How to cite: Valentim, R. \& Louzada, R. 2020. A new record of Tillandsia candida Leme (Bromeliaceae, Tillandsioideae) and notes on its taxonomy. Hoehnea 47: e132019. http://dx.doi.org/10.1590/2236-8906-13/2019

\begin{abstract}
A new record of Tillandsia candida Leme (Bromeliaceae, Tillandsioideae) and notes on its taxonomy). Tillandsia candida Leme is a Brazilian endemic species known only from its type specimen. In this work, it is presented new distributional records for the species, located $205 \mathrm{~km}$ from the type locality. In addition, a morphological description and illustrations of vegetative and reproductive characters are presented, as well as updated data on the conservation status of the species.
\end{abstract}

Keywords: Anoplophytum, Bahia, endemism, Morro do Chapéu, taxonomy

RESUMO - (Um novo registro de Tillandsia candida Leme (Bromeliaceae, Tillandsioideae) e notas taxonômicas). Tillandsia candida Leme é uma espécie endêmica do Brasil conhecida apenas pelo seu espécime tipo. Neste trabalho, apresentamos novos registros de ocorrência para a espécie, localizados a $205 \mathrm{~km}$ da população tipo. Adicionalmente é apresentada uma descrição morfológica e ilustrações dos caracteres vegetativos e reprodutivos, além de dados atualizados sobre o status de conservação da espécie.

Palavras-chave: Anoplophytum, Bahia, endemismo, Morro do Chapéu, taxonomia

\section{Introduction}

Tillandsia L. accounts for the greatest diversity in Bromeliaceae with approximately 741 species (Gouda et al. 2018). It is distributed from the southern United States to the Antilles and central Argentina and Uruguay, with centers of diversity in northern Central America and the northern and central Andes (Barfuss et al. 2016).

The genus is composed mostly of epiphytic herbs (Barfuss et al. 2016). In Brazil, it is distributed in all phytogeographic domains (Flora do Brasil 2020), mainly in dry forests such as the Caatinga. However, there have been few studies on the diversity of Tillandsia in this environment (Pontes \& Agra 2006).

According to the Flora do Brasil (2020), Tillandsia is represented by 87 species in Brazil, of which 50 are endemic. In the State of Bahia, there occur 27 species, being ten endemic. Tillandsia is divided into seven subgenera: Aerobia Mez, Anoplophytum Beer, Diaphoranthema Beer, Phytarrhiza Vis., Pseudovriesea Barfus, Viridantha Espejo, and Tillandsia L. (Barfuss et al. 2016). According to Tardivo (2002), Tillandsia subg. Anoplophytum is the most diverse in Brazil and presents the highest number of restricted species.

Tillandsia candida Leme is one of the restrict species within subgenus Anoplophytum. It is a small plant recognized mainly by its filiform or sublinear leaves, non-globose inflorescence, and white petals (Leme 1987, Fiorato 2009), whose description is based on a single specimen [A. Seidel 975 (HB)] collected in the city of Nova Itarana, Bahia (Leme 1987). Until now, the species was known from a single locality, making $T$. candida an endemic taxon from the State of Bahia (Flora do Brasil 2020).

Accordingly, the present study addresses the discovery of a new record of a rare bromeliad species found in gallery forests and in an urban area within the Caatinga domain. The population was found about $205 \mathrm{~km}$ from the type locality, expanding the geographical distribution and contributing with new information regarding the conservation status of this species. In addition, a full description and an illustration with details of the reproductive traits based on the new

1. Universidade Federal de Pernambuco, Departamento de Botânica, Laboratório de Morfo-Taxonomia Vegetal, Avenida Professor Moraes Rego, 1235, Cidade Universitária, 50670-901 Recife, PE, Brasil

2. Corresponding author: rayssavalentim@live.com 
records in order to facilitate the recognition of the species and improve the taxonomic understanding of this taxon is presented.

\section{Material and methods}

The specimen was collected during fieldwork at the Reserva Estadual do Morro do Chapeu, in the Brazilian State of Bahia. This reserve is located in the northern portion of the Chapada Diamantina mountain range and is characterized by quartzite rocky outcrops and campo rupestre vegetation.

The area represents the Bahian portion of the Cadeia do Espinhaço mountain range, which is highlighted by the rock formations reaching altitudes of $1,000 \mathrm{~m}$ a.s.l., the herbaceous-shrubby vegetation, a climate with wide temperature variations and water deficits, and thus constitutes a xerophytic vegetation (Giulietti et al. 1997, Rapini 2008).

The studies were undertaken based on dry and fresh material conserved in $70 \%$ ethanol. Sterile specimens were kept under cultivation. Morphological structures were analyzed in a stereomicroscope using the definitions of Stearn (1992). For the stigma type, we used the terminology of Brown \& Gilmartin (1989).

The dried material was deposited at the Herbarium of the Universidade Federal de Pernambuco UFP; acronym according to Thiers (2016) (continuously updated)]. The conservation status of Tillandsia candida was evaluated based on the IUCN (2014) combined with a GeoCAT analysis (Bachman et al. 2011). The geographic distribution map was produced using the QGIS 2.18 software (QGIS Development Team 2018) and a database of geographical coordinates of the collected specimens.

\section{Taxonomic treatment}

Tillandsia candida Leme, Bradea 4 (50): 397. 1987.

Type: Brazil - Bahia, Nova Itarana, ca. 1,000 m elev. A. Seidel 975 (HB-image!, flowered under cultivation in August 1987).

Figure 1-2

Epiphyte and rupicolous, ca. $10 \mathrm{~cm}$ tall, stem short, ca. 5 $\mathrm{cm}$ long. Leaves numerous, 30-35 leaves, spiral-spreading; sheaths $4 \times 4 \mathrm{~mm}$, large-triangular, green, lepidote on both surfaces, margins entire; blades $5-7 \times 0.3 \mathrm{~cm}$, narrowtriangular, green, subcoriaceous, margins entire, lepidote on both surfaces, apex filiform. Inflorescence ca. $4.5 \mathrm{~cm}$ long; peduncles ca. $3 \mathrm{~cm}$ long, delicate, green; peduncle bracts ca. $3.5 \mathrm{~cm}$ long, narrow-triangular, green, lepidote on both surfaces, margins entire, apex acuminate; fertile portion of the inflorescences ca. $1.5 \mathrm{~cm}$ long, composite distichous, ca. 3 flowers. Floral bracts 1.5-2.5 $\times 0.4 \mathrm{~cm}$, narrow-ovate, reddish at the base, green at the apex, lepidote on both surfaces, margins entire, apex acuminate. Flowers sessile; sepals 3: 2 connate at the base, ca. $9 \times 4 \mathrm{~mm}$, free portion ca. $2 \mathrm{~mm}$ long, and 1 free, ca. $7 \times 2 \mathrm{~mm}$, lanceolate, apex attenuate or acute; petals $1.4 \times 3 \mathrm{~cm}$, oblanceolate, white, lobes apiculate at the apex. Stamens 6: 3 adnate to the base of the petals, free part of the filaments ca. $2 \mathrm{~mm}$ long, and 3 free, ca $8 \mathrm{~mm}$ long; anthers ca. $1 \mathrm{~mm}$ long, linear, opposite to the petals, dorsifixed; style ca. $7 \mathrm{~mm}$ long, terminal; stigma ca. $1 \mathrm{~mm}$ long, spiral-conduplicate; ovary ca. $3 \mathrm{~mm}$ long, cylindrical. Seeds not seen.

Material examined: BRAZIL. BAHIA: Morro do Chapéu, Ventura Village, Ventura Waterfall, $11^{\circ} 41^{\prime} 05.97$ 'S $41^{\circ} 01$ '40.35”'W, VIII-2016, R. Louzada 224 (UFP).

Geographical distribution - Tillandsia candida is endemic to Bahia (Fig. 3). The specimen here analyzed was collected in a gallery forest of an urban area, growing about $3 \mathrm{~m}$ from the ground as an epiphyte.

Conservation status - Considering the IUCN (2014) criteria, Tillandsia candida was previously classified as Vulnerable (VU) due to an EOO $<2,000 \mathrm{~km}^{2}$ (Romand 2014). It was also classified as Critically Endangered (CR) based on the GBIF (2017) data $\left(E O O=0,000 \mathrm{~km}^{2}\right.$ and AOO $\left.4,000 \mathrm{~km}^{2}\right)$. However, according to the new evidence, the species should be classified in the category Endangered (EN), considering that the current $\mathrm{AOO}$ is $16,000 \mathrm{~km}^{2}$ and the criterion $\mathrm{B} 2 \mathrm{~b}$ (ii) is fulfilled.

Comments - Tillandsia candida belongs to the subgenus Anoplophytum, which is characterized by including species commonly found in xeric environments, with spirally arranged leaves, compound inflorescences, symmetrical sepals, tubular corolla, odorless flowers, included filaments, and simpleerect stigmas (which contrasts with the spiral-conduplicate stigmas observed in T. candida). The species of the subgenus Anoplophytum are found from eastern and southern Brazil to Bolivia, Argentina, and Uruguay (Benzing 2000). Leme (1987) describes green floral bracts for T. candida, but here we highlight the reddish tone of floral bracts.

Fiorato (2009) highlighted the similarities between Tillandsia recurvata $(\mathrm{L})$. L and $T$. candida Rudder in relation to the size and shape of leaves. Leme (1987) and Fiorato (2009) commented on the morphological similarity between T. candida and T. tenuifolia Rudder. However, our results suggest differences in the vegetative and reproductive features among these species (Table 1).

While Tillandsia tenuifolia has longer and wider leaf blades, T. candida leaves are shorter and narrower, besides presenting a difference in the reproductive portion, where the floral bracts are reddish in T. candida and pale pinkish in $T$. tenuifolia. Differences also can be seen in the reproductive portion, between $T$. candida and $T$. reccurvata where the floral bracts reddish and larger than the sepals with one apex acuminate in $T$. candida, while in $T$. recurvata the floral bracts are shorter and have a sharp apex. In addition, 


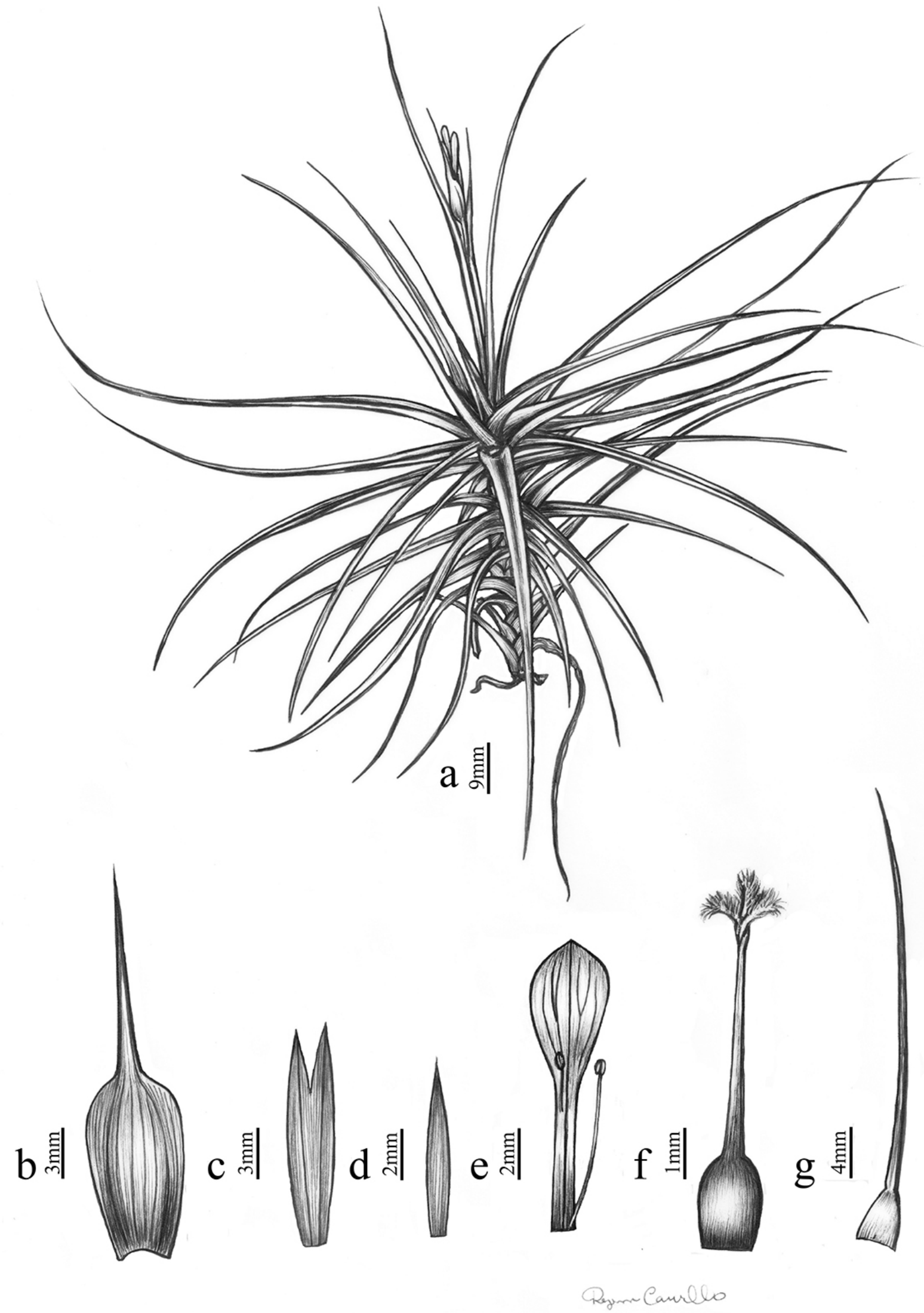

Figure 1. Tillandsia candida Leme. a. Habit. b. Floral bracts. c. Connate sepals. d. Free sepal. e. Petal. f. Gynoecium. g. Peduncle bracts. 

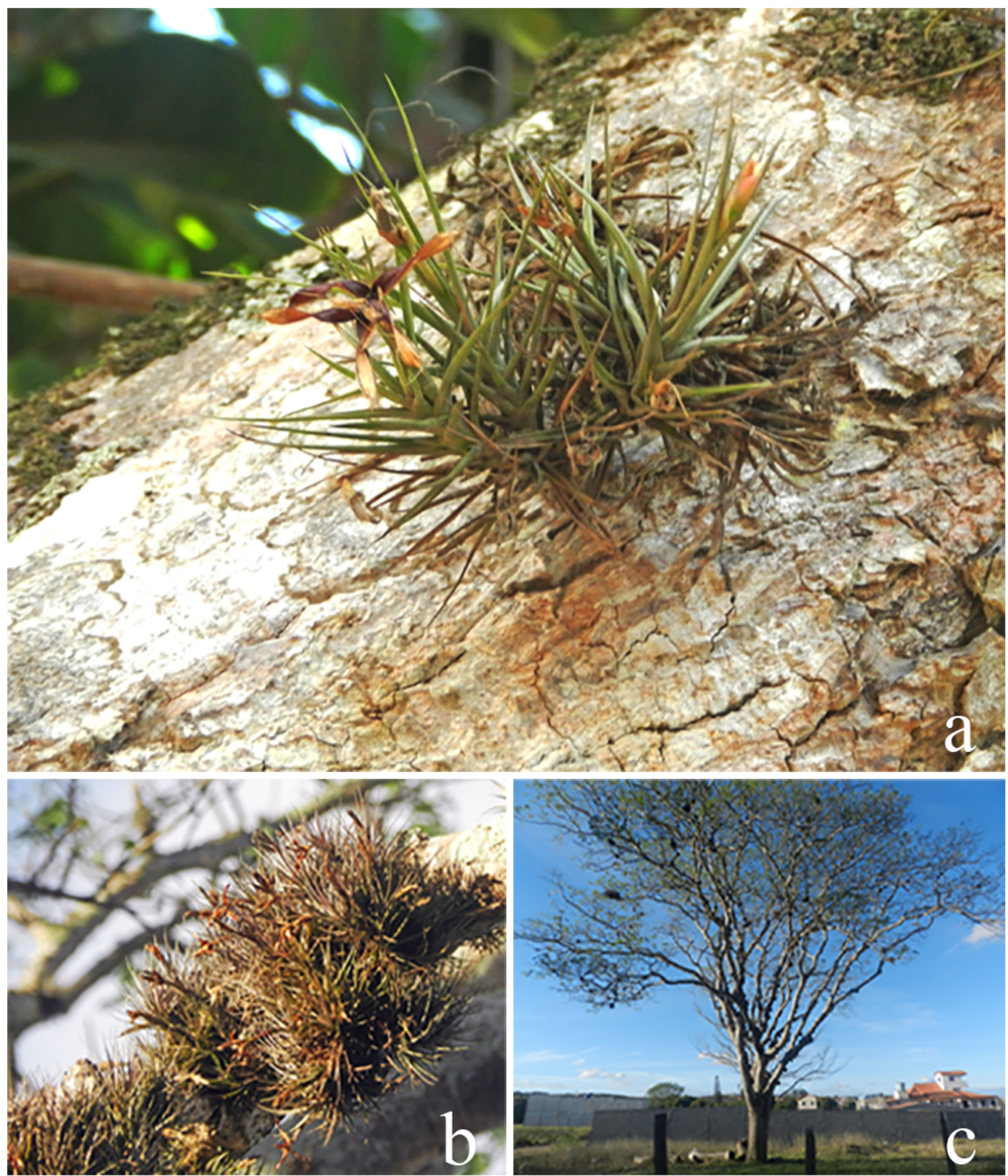

Figure 2. Tillandsia candida Leme. a. Habit. b. Habit. c. Phorophyte. Fonte: Autores.

Table 1. Comparison of Tillandsia candida Leme and morphologically related species.

\begin{tabular}{lccc}
\hline Characters & Tillandsia candida & Tillandsia tenuifolia & Tillandsia recurvata \\
\hline Leaf shape & narrow-triangular & narrow-triangular & linear-triangular \\
Floral bract shape and color & apex acuminate, reddish & $\begin{array}{c}\text { apex slightly cuspidate, } \\
\text { pink }\end{array}$ & apex acute, vinaceous \\
Inflorescence color & white & purple to blue & blue to white \\
Inflorescence size & $1.5 \mathrm{~cm}$ & $3.0 \mathrm{~cm}$ & $1.5 \mathrm{~cm}$ \\
Stigma & spiral-conduplicate & simple-erect & simple-erect \\
\hline
\end{tabular}




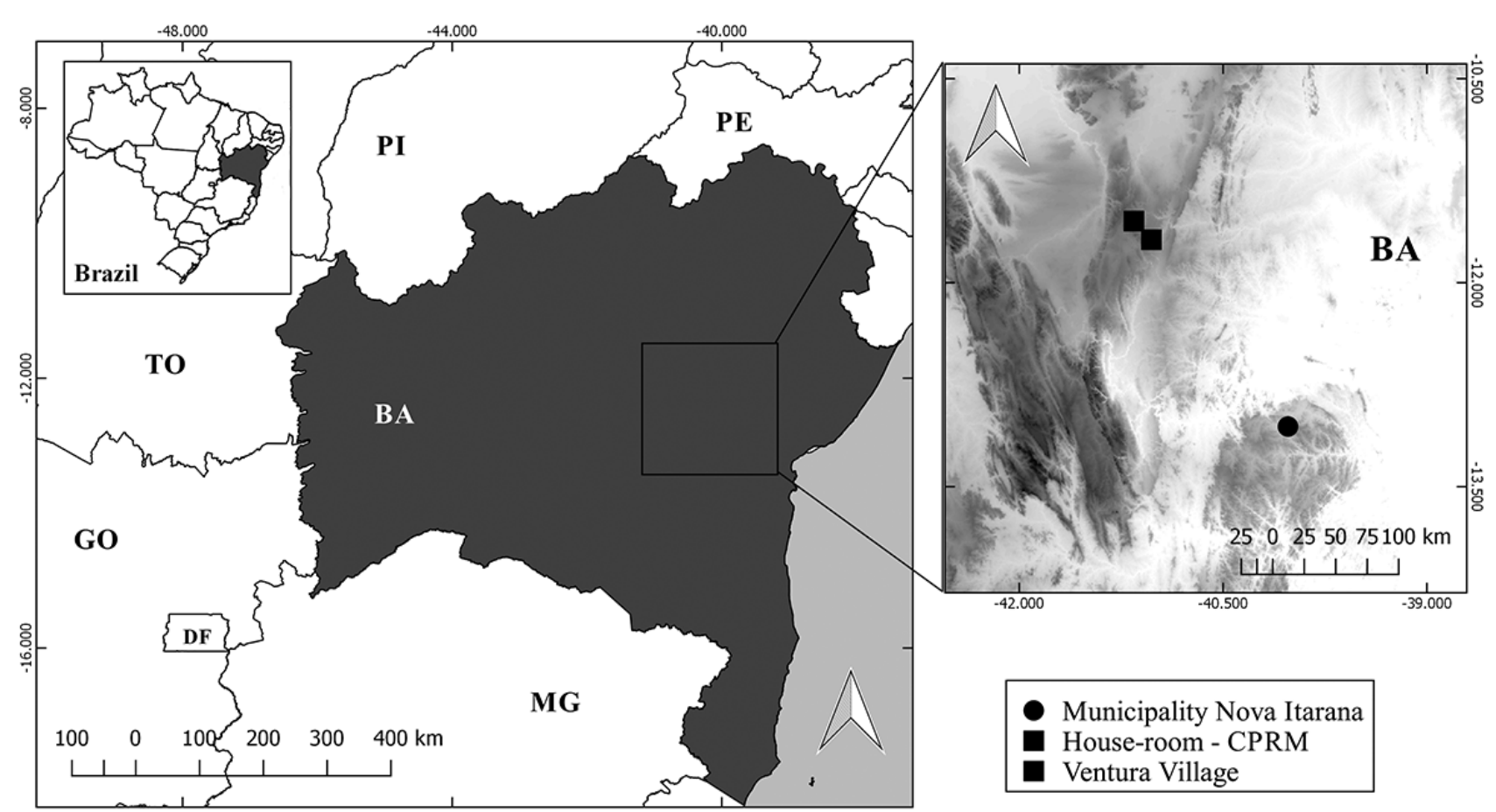

Figure 3. Geographic distribution of Tillandsia candida Leme. (•) Type locality, ( $\bullet$ ) Populations of the new records. PE: Pernambuco State; BA: Bahia State; PI: Piauí State; TO: Tocantins State; GO: Goiás State; DF: Distrito Federal; MG: Minas Gerais State.

these two species are also different in relation to the color of the petals, lilac in T. recurvata and white in T. candida.

The knowledge about the distribution and reproductive biology of Tillandsia candida is still incipient. The only records available for this species were those of the protologue and one additional record found on the Reflora - Herbário virtual (2019) website: "without locality, s.d., Blanchet 2982 (W)". The last record was misidentified and later the current authors found it to be T. candida, Therefore, the available data regarding this taxon is insufficient, either in relation to its habitat or the size of its populations.

According to Rabinowitz (1981), in order to consider a species rare, one has to take into account three aspects: (1) geographic range; (2) habitat specificity; (3) local population size. Tillandsia candida has a limited geographic range, based on the recorded populations. As with the other species of Anaplophytum, this plant is presumed to be found in a xeric domain. However, the habitat where we collected the specimens studied here was a moist gallery forest and an urban area. The populations observed comprised a few individuals and did not represent a dominant epiphyte on the trees, except in the urban area where a greater number of individuals were observed, however, only with a few plants. Thus, we conclude that this species is considered rare considering Rabinowitz's criteria.

\section{Acknowledgments}

The authors thank Dr. Edlley Pessoa for assistance during the collection of botanical material and Regina Carvalho for the illustration of the specimen.

\section{Literature Cited}

Bachman, S., Moat, J., Hill, A.W., de la Torre, J. \& Scott, B. 2011. Supporting Red List threat assessments with GeoCAT: geospatial conservation assessment tool. ZooKeys 150: 117-126.

Barfuss, M.H., Till, W., Leme, E.M., Pinzón, J.P., Manzanares, J.M., Halbritter, H. \& Brown, G.K. 2016. Taxonomic revision of Bromeliaceae subfam. Tillandsioideae based on a multi-locus DNA sequence phylogeny and morphology. Phytotaxa 279(1): 1-97.

Benzing, D.H. 2000. Bromeliaceae Profile of an Adaptive Radiation. Cambridge University Press.

BFG (The Brazil Flora Group). 2015. Growing knowledge: an overview of Seed Plant diversity in Brazil. Rodriguésia 66: 1085-1113.

Brown, G.K. \& Gilmartin, A.J. 1989. Stigma types in Bromeliaceae - a systematic survey. Systematic Botany 14: 110-132. 
Fiorato, L. 2009. O gênero Tillandsia L. (Bromeliaceae) no estado da Bahia, Brasil. Dissertação de mestrado. Instituto de Botânica da Secretaria de Estado do Meio Ambiente, São Paulo.

Giulietti, A.M., Pirani, J.R. \& Harley, R.M. 1997. Espinhaço range region eastern Brazil. In: Centres of plant diversity: a guide and strategy for their conservation.

Gouda, E.J., Butcher, D. \& Gouda, C.S. 2018 (continuously updated). Encyclopedia of Bromeliads, Version 4. University Botanic Gardens, Utrecht. Available from http:// bromeliad.nl/encyclopedia/ (accessed on 15-I- 2019).

Harris, J.G. \& Harris, M.W. 2001. Plant Identifications Terminology: An Illustrated Glossary. 2 ed. Spring Lake, Utah.

IUCN Standards and Petitions Subcommittee. 2014. Guidelines for Using the IUCN Red List Categories and Criteria. Version 11. Prepared by the Standards and Petitions Subcommittee. Available from http://www. iucnredlist.org/documents/RedListGuidelines.pdf

Leme, E.M.C. 1987. Novas Bromeliáceas Nativas do Brasil-V. Bradea 4: 397-398.

Pontes, R. A. S., \& Agra, M.F. 2006. Flora da Paraíba, Brasil: Tillandsia L. (Bromeliaceae). Rodriguésia, pp. 47-61.

QGIS Development Team. 2018. QGIS Geographic Information System. Open Source Geospatial Foundation Project. Available from http://qgis.osgeo.org

Rabinowitz, D. 1981. Seven forms of rarity. In: H. Synge (ed.). The biological aspects of rare plant conservation. Chichester: John Wiley, pp. 205-217.
Rapini, A., Ribeiro, P.L., Lambert, S., \& Pirani, J.R. 2008. A flora dos campos rupestres da Cadeia do Espinhaço. Megadiversidade, 4(1-2): 16-24.

Reflora - Herbário Virtual. 2019. Available from http:// reflora.jbrj.gov.br/reflora/herbarioVirtual/ (accessed on 5-II-2019).

Romand-Monnier, F. 2014. Tillandsia candida. A IUCN Lista Vermelha de Espécies Ameaçadas de 2014: e. T44392544A44494099. Available from http://dx.doi.org/10.2305/IUCN.UK.2014-1.RLTS. T44392544A44494099.en (accessed on 15-I-2019).

Stearn, W.T. 1966. Botanical Latin. Thomas Nelson Ltd., Great Britain.

Tardivo, R.C. 2002. Revisão taxonômica de Tillandsia L. subgênero Anoplophytum (Beer) Baker (Bromeliaceae). Tese de doutorado, Universidade de São Paulo, São Paulo.

Thiers, B. 2016. (continuously updated). Index Herbariorum: A global directory of public herbaria and associated staff. New York Botanical Garden's Virtual Herbarium. Available from http://sweetgum.nybg.org/science/ih/ (accessed on 29-IX-2017)

Tillandsia in Flora do Brasil 2020 em construção. Jardim Botânico do Rio de Janeiro. Available from http:// floradobrasil.jbrj.gov.br/reflora/floradobrasil/FB6361 (accessed on 15-I-2019).

Tillandsia candida Leme in GBIF Secretariat. 2017. GBIF Backbone Taxonomy. Checklist dataset. Available from https://doi.org/10.15468/39omei - accessed via GBIF. org (accessed on 15-I-2019). 